\title{
Perencanaan dan Implementasi SAP pada PT XYZ dengan Menggunakan Metode Accelerated SAP (ASAP)
}

\author{
Rahma Maulidina, Nur Anisa Rizki, Renny Sari Dewi \\ Fakultas Teknologi Informasi dan Kreatif, Sistem Informasi, Universitas Internasional Semen Indonesia, Gresik, Indonesia \\ Email: ${ }^{1}$ rahma.maulidina16@student.uisi.ac.id, ${ }^{2}$ nur.rizki16@student.uisi.ac.id, ${ }^{3}$ renny.dewi@uisi.ac.id
}

Submitted 28-12-2019; Accepted 04-02-2020; Published 15-02-2020

\begin{abstract}
Abstrak
Sistem informasi yang terintegrasi merupakan kebutuhan untuk membantu menyelesaikan permasalahan dalam pengelolaan transaksi bisnis. Aplikasi SAP adalah salah satu aplikasi yang mampu memberikan solusi permasalahan tersebut. Tujuan penulisan penelitian ini adalah untuk merencanakan proses bisnis yang berjalan, merencanakan implementasi sistem SAP berjalan yang berhubungan dengan implementasi dan maintenance aplikasi SAP dan memberikan saran pengembangan berdasarkan hasil perencanaan yang diperoleh, dilihat dari segi Proses bisnis, kinerja, dan financial. Untuk analisis digunakan metode IT Balanced Scorecard, sementara untuk pengembangan sistem digunakan metodologi ASAP (Accelerated SAP). Penelitian ini menghasilkan analisis tentang perencanaan dari proses bisnis perusahaan dalam melakukan implementasi pengembangan sistem ERP SAP financial and controlling.
\end{abstract}

Kata Kunci: Sistem Informasi, Perencanaan, Implementasi, ERP, SAP

\begin{abstract}
An integrated information system is a need to help solve problems in managing business transactions. SAP application is one application that is able to provide solutions to these problems. The purpose of writing this research is to plan running business processes, plan implementation of the current SAP system related to the implementation and maintenance of SAP applications and provide development suggestions based on the results of planning obtained, in terms of business processes, performance, and financial. For the analysis, the IT Balanced Scorecard method is used, while for system development the ASAP (Accelerated SAP) methodology is used. This research produces an analysis of the planning of the company's business processes in implementing the implementation of the SAP financial and controlling ERP.
\end{abstract}

Keywords: Information Systems, Planning, Implementation, ERP, SAP

\section{PENDAHULUAN}

Seiring perkembangan zaman, banyak sistem informasi dari perusahaan yang tidak dapat memenuhi proses bisnis dalam perusahaan secara keseluruhan. Masalah yang mungkin timbul adalah perusahaan memiliki sistem yang tidak terintegrasi. banyak perusahaan menggunakan ERP (Enterprise Resource Planning) yang besar untuk membuat integrasi terhadap subsistem yang ada dalam perusahaan tersebut menjadi satu aplikasi / program. Contoh dari software semacam itu adalah SAP, yang menggabungkan sistem informasi akuntansi dan sistem informasi manajemen menjadi suatu sistem yang mencakup seluruh bagian di perusahaan. Keuntungannya adalah sistem informasi yang terintegrasi secara lengkap untuk menangani proses bisnis perusahaan secara keseluruhan, strategi bisnis dapat diimplementasikan sesuai dengan operasi bisnis perusahaan, meningkatkan produktivitas dan memperoleh pengetahuan yang mendalam terhadap bisnis perusah aan. meminimalkan biaya dengan meningkatkan fleksibilitas di saat yang sama meminimalkan resiko bisnis, mengoptimalkan manajemen keuangan dan kebijakan perusahaan,mempercepat tercapainya ROI perusahaan. Tingginya persaingan dalam meningkatkan jumlah konsumen dengan pelayanan cepat dan biaya yang murah menuntut PT XYZ untuk menggunakan teknologi informasi sebagai salah satu penunjang kinerja karyawan dalam melakukan proses dan kegiatan operasional yang tadinya manual menjadi otomatis. salah satunya adalah ERP enterprise Resource Planning ERP menggunakan SAP diyakini dapat memberikan solusi bisnis bagi perusahaan untuk dapat menghasilkan informasi secara real time up to date.

Secara teknis, Sistem ERP berfungsi untuk mengintegrasikan berbagai sistem informasi yang tersebar pada departemen (unit fungsional) suatu Perusahaan. Dengan adanya sistem ERP tersebut, maka unit fungsional terkait dapat saling berbagi informasi yang pada akhirnya dapat meningkatkan sinergi perusahaan. Sistem ERP membantu dalam melakukan standarisasi proses operasi melalui implementasi best practice, sehingga terjadi peningkatan produktivitas, penurunan in-efisiensi, dan peningkatan kualitas produk. Dalam pencapaian standarisasi proses operasi tersebut, terlebih dahulu dilakukan standarisasi data dan informasi melalui keseragaman pelaporan, terutama untuk perusahaan yang memiliki banyak unit bisnis dengan jumlah dan jenis yang berbeda.

Tujuan dari proyek ini adalah untuk mendukung atau membantu menjalankan operasional secara lebih efektif dan efisien. selain itu juga membantu perusahaan PT XYZ dalam merencanakan dan melakukan berbagai kegiatan finansial sehari - hari. diharapkan dengan berjalanya proyek ini PT XYZ dapat berjalan sehingga tercapainya standar pelaporan perusahaan yang terpenuhi. Modul FI (Financial) terdapat beberapa bagian, yaitu laporan buku besar, pemrosesan piutang usaha dan utang usaha, seperti pencatatan jurnal dalam setiap transaksi penjualan dan pembelian, dan aset tetap perusahaan. Selain itu, modul FI juga menyertakan perhitungan pajak yang terkait dalam proses binis perusahaan.

\section{METODE PENELITIAN}

\subsection{Sistem Informasi}


Sistem dapat didefinisikan sebagai suatu kumpulan atau himpunan dari unsur, komponen atau variabel yang terorganisir, saling berinteraksi, saling tergantung satu sama lain, dan terpadu. Maksud dari komponen atau subsistem di dalam pengertian ini tidak hanya komponen fisik semata, tetapi termasuk di dalamnya adalah komponen yang bersifat abstrak atau komponen secara konseptual, seperti visi, misi, kebijakan, prosedur, dan kegiatan informal lainnya.[1] Sistem informasi adalah suatu sistem yang menyediakan informasi untuk manajemen dalam mengambil keputusan dan juga untuk menjalankan operasional perusahaan, dimana sistem tersebut merupakan kombinasi dari orang-orang, teknologi informasi dan prosedur-prosedur yang terorganisasi. Sistem informasi adalah suatu sistem yang terdapat di dalam sebuah organisasi yang saling berintegrasi dan bekerja sama satu sama lain untuk mencapai tujuan yang sama. Sistem informasi memiliki beberapa komponen yaitu komponen input, komponen model, komponen output, komponen teknologi, komponen basis data, komponen kontrol. Jadi, sistem informasi adalah suatu sistem yang saling terintegrasi yang menyediakan informasi untuk membantu sebuah organisasi dalam mengontrol kinerja proses bisnis jadi sistem informasi adalah suatu system yang saling terintegrasi dan bekerja sama untuk mengumpulkan, memroses, menyimpan dan menyebar informasi untuk membantu sebuah organisasi dalam pengendalian sistem untuk mencapai tujuan organisasi[2].

\subsection{Perencanaan}

Perencanaan adalah suatu proses identifikasi untuk mendefinisikan apakah suatu kegiatan atau program yang dilaksanakan sesuai dengan rencana atau tujuan yang ingin dicapai. Perencanaan adalah suatu kegiatan mengumpulkan informasi mengenai kinerja sesuatu (metode, manusia, peralatan), dimana informasi tersebut akan dipakai untuk menentukan alternative terbaik dalam membuat keputusan. Jadi, Perencanaan adalah proses menetapkan tujuan untuk dapat dicapai dimana rencana tersebut didasarkan atas tujuan yang telah ditetapkan, yang selanjutnya diikuti dengan pengambilan keputusan atas obyek yang ingin dicapai. Adanya proses perencanaan dapat membantu mengatasai salah satu rintangan penting yaitu keuangan dan sumber daya manusia yang terkait dengan IT[3].

\subsection{Implementasi}

Implementasi adalah suatu penerapan atau tindakan yang dilakukan berdasarkan rencana yang telah disusun atau dibuat dengan cermat dan terperinci sebelumnya. Setelah sistem dianalisa dan dirancang, kemudian sistem siap diterapkan atau diimplementasikan. Implementasi merupakn tahap dimana sistem informasi sudah digunakan oleh pengguna. Tahapan tahapan implementasi terdiri atas User dan roles, setup User dan hak akses, master data, install modul, dan install database[4].

\subsection{ERP}

Enterprise Resource Planning (ERP) adalah perangkat lunak utama dari perusahaan yang bekerja untuk mengintegrasikan informasi yang ada di semua bidang bisnis yang memiliki tujuan untuk dapat merencanakan dan mengelola semua sumber daya yang tersedia bagi suatu perusahaan sehingga semua bisnis area dalam perusahaan bisa berjalan dengan baik. Sistem ERP juga terdiri dari beberapa modul yang terintegrasi dengan satu sama lain, termasuk manajemen material, penjualan dan distribusi, perencanaan produksi, keuangan, sumber daya manusia, dan lain-lain [5]. Enterprise Resources Planning (ERP), merupakan suatu perangkat lunak software dengan aplikasi yang terintegrasi dengan baik dan digunakan secara luas dalam organisasi bisnis. Aplikasi-aplikasi yang terintegrasi tersebut biasanya digolongkan berdasarkan fungsi-fungsi operasional dalam bisnis, yaitu: akuntansi, keuangan, sumber daya manusia, pemasaran, logistik dan lainnya[6]. Pada saat ini ada beberapa aplikasi berbasis ERP diantaranya: OpenERP atau Odoo, Oracle, SAP (System Application and Product in data processing), IFS (Industrial and Financial System) dan lain-lain[7].

\subsection{SAP}

SAP (System Application and Product) adalah suatu software yang dikembangkan untuk mendukung suatu organisasi dalam menjalankan kegiatan operasionalnya secara lebih efisien dan efektif. SAP juga merupakan software Enterprise Resources Planning (ERP), yaitu suatu tools IT dan manajemen untuk membantu perusahaan merencanakan dan melakukan berbagai aktivitas sehari-hari. SAP terdiri dari sejumlah modul/aplikasi yang mempunyai kemampuan mendukung semua transaksi yang erlu dilakukan suatu perusahaan dan tiap aplikasi bekerja secara berkaitan satu dengan yang lainnya[8]. SAP dikenal karena merupakan salah satu ERP yang menyediakan best practice dari perusahaan-perusahaan ternama di dunia, sehingga memberikan panduan bagi perusahaan yang mengimplementasikannya bagaimana praktik terbaik yang seharusnya dijalankan agar performa perusahaan tersebut meningkat seiring dengan diimplementasikannya SAP ERP tersebut[9].

\subsection{ASAP}

Accelerated SAP (ASAP) Methodology adalah pendekatan yang direkomendasikan SAP untuk mengimplementasikan software ERP di perusahaan. SAP memanfaatkan inti dari metodologi dan alat untuk mengembangkan secara cepat, hasil yang dapat diandalkan, dan untuk membantu pengguna mendapatkan solusi yang terbaik untuk suatu bisnis. Selain itu ASAP memiliki keunggulan dalam tata kelola proyek, manajemen kualitas, dan pedoman untuk implemetasi proyek dan manajemen proses bisnis yang efisien. [10]. Standar metodologi ASAP dibangun disekitar SAP advanced delivery management model dan mendukung tim proyek dengan templates, peralatan, kuisioner dan daftar list dan termasuk buku panduan. Standar metodologi ASAP memberdayakan perusahaan untuk menggunakan fitur yang berkembang dan peralatan yang telah dibangun pada solusi SAP[11]. 
Berikut dapat dilihat melalui gambar 1. fase dari Accelerated SAP

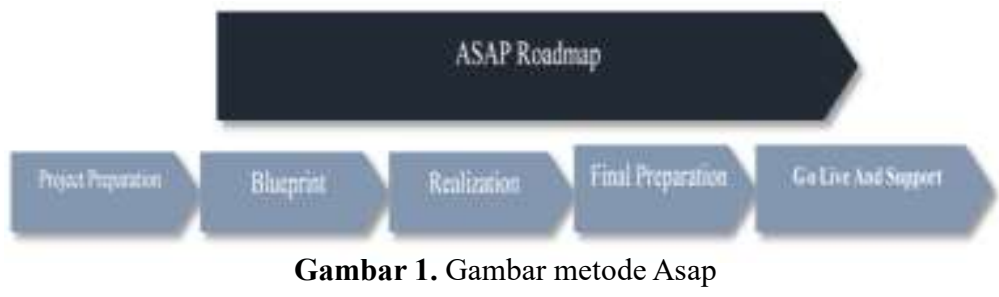

\section{ANALISA DAN PEMBAHASAN}

Pada bagian ini berisi analisa, hasil serta pembahasan dari topik penelitian, yang bisa di buat terlebih dahulu metodologi penelitian. Bagian ini juga merepresentasikan penjelasan yang berupa penjelasan, gambar, tabel dan lainnya.

\subsection{Project Preparation}

Pada project preparation, penelitian diawali dengan studi lapangan untuk mendapatkan latar belakang dilakukannya penelitian ini. Selanjutnya, dilakukan perumusan masalah untuk pembangunan sistem. Setelah itu, menetapkan ruang lingkup permasalahan dan tujuan penelitian untuk hasil yang ingin dicapai dari permasalahan yang ada. Kemudian, melakukan studi literatur yaitu, pencarian referensi yang dibutuhkan dalam pembangunan sistem berdasarkan buku, paper, dan jurnal[12]

\section{a. Timeline Project}

Tabel 1. Timeline Project

\begin{tabular}{llllll}
\hline \multicolumn{1}{c}{ Assigned To: } & \multicolumn{4}{c}{ Bulan } \\
& $\mathbf{1}$ & $\mathbf{2}$ & $\mathbf{3}$ & $\mathbf{4}$ & $\mathbf{5}$ \\
\hline Melakukan interview & & & & & \\
pada stakeholder & & & & & \\
Analisa hasil interview & & & & & \\
Implementasi dan & & & & & \\
instalasi software & & & & & \\
Simulation Project & & & & & \\
Tesing Aplikasi & & & & \\
\hline
\end{tabular}

\section{b. Project Team Management}

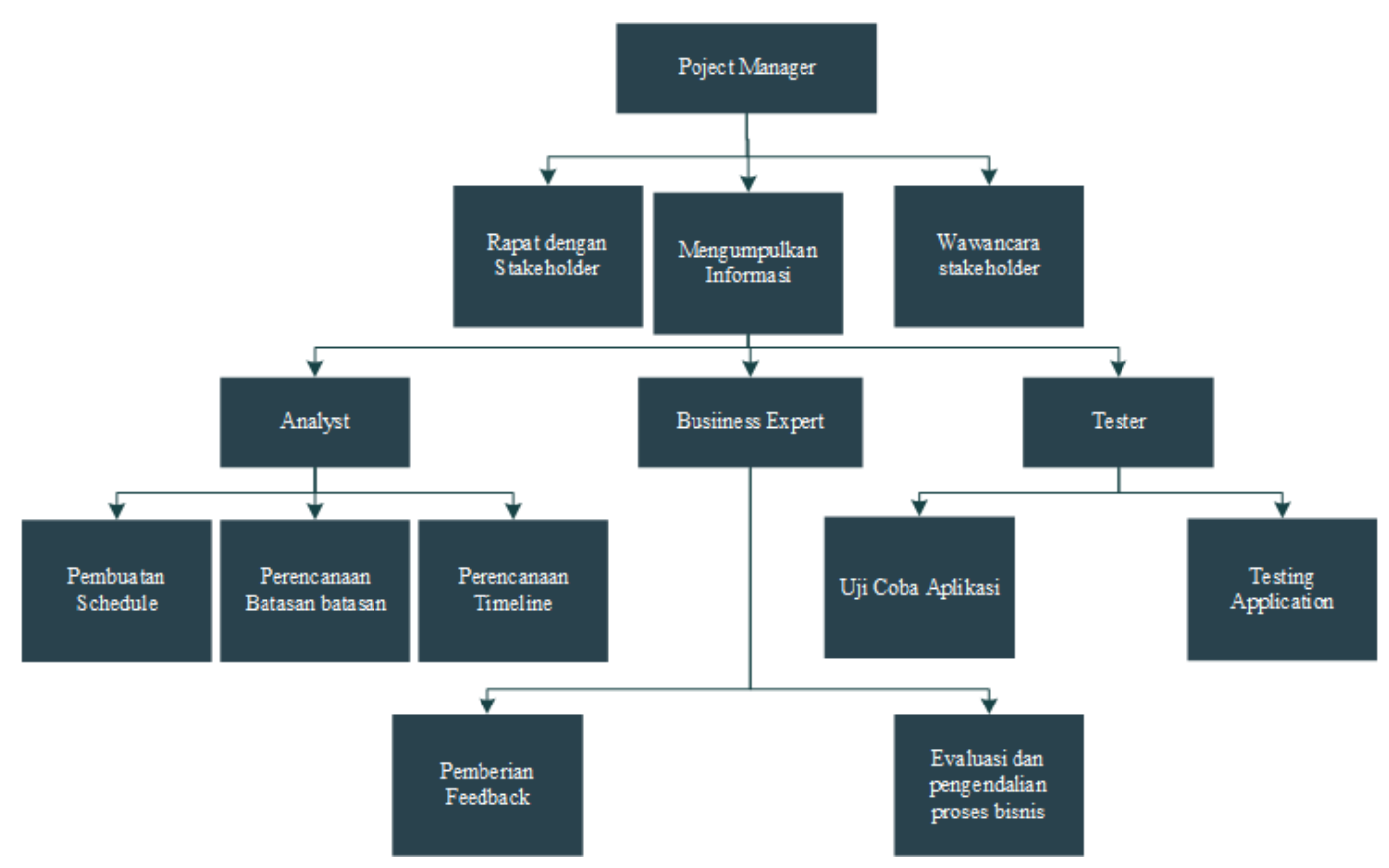

Gambar 2. Struktur Organisasi 


\section{c. Project Scope Management}

Tabel 2. Ruang Lingkup Management

\begin{tabular}{l|l}
\hline \multicolumn{1}{c|}{ Goals } & \multicolumn{1}{c}{ Objectives } \\
\hline $\begin{array}{l}\text { Proyek implementasi SAP pada perussahaan } \\
\text { PT.XYZ }\end{array}$ & $\begin{array}{l}\text { 1. Melakukan interview kepada pimpinan PT. XYZ } \\
\text { 2. Melakukan interview kepada konsultan IT PT. XYZ } \\
\text { 3. Merumuskan rencana pengadaan server pada PT. XYZ }\end{array}$ \\
$\begin{array}{l}\text { Proyek akan memberikan dan mengembangkan } \\
\text { fitur untuk SAP dalam bidang pelaporan finansial } \\
\text { terkait proses bisnis }\end{array}$ & $\begin{array}{l}\text { Menyiapakan storage untuk instalasi SAP serta data data } \\
\text { olahan SAP. }\end{array}$ \\
\end{tabular}

\subsection{Blueprint}

Dalam tahap ini menjelaskan bagaimana perjanjian yang dilakukan antara stakeholder dengan client. Proses yang dilakukan antara lain yakni, mendefinisikan standard document yang ada di SAP, mengikutsertakan user requirement yang telah ditentukan, serta memberikan feedback.

\section{a. Communication Matrix}

Matriks Komunikasi adalah instrument penilaian yang dibuat untuk memberikan support terhadap komunikasi yang dilakukan antara stakeholder dengan client. Berikut dilihat pada Tabel 3:

Tabel 3. Communication Matrix Table

\begin{tabular}{|c|c|c|}
\hline Stakeholder & Messages & Frequency \\
\hline Sistem Analyst & $\begin{array}{l}\text { 1. Pertemuan dalam penentuan dan persetujuan anggota tim } \\
\text { pelaksana } \\
\text { 2. Mengalokasikan waktu dan timeline Pengerjaan proyek } \\
\text { berjalan sesuai. } \\
\text { 3. Melakukan analisa terhadap rancangan Server Experts } \\
\text { 4. Menghubungi Stakeholder } \\
\text { 5. Memberikan Informasi spesifikasi kebutuhan secara spesifik }\end{array}$ & Sering \\
\hline Project Manager & $\begin{array}{l}\text { 1. Menganalisa tingkat resiko } \\
\text { 2. Peningkatan kualitas kerja } \\
\text { 3. Sebagai pengingat } \\
\text { 4. Sebagai koordinator tertinggi dalam keberhasilan kerja team. }\end{array}$ & Sering \\
\hline Bussiness Expert & $\begin{array}{l}\text { 1. Sebagai koordinator terkait proses } \\
\text { 2. Sebagai komponen tertinggi dalam pengendalian } \\
\text { dan alur proses bisnis. }\end{array}$ & $\begin{array}{l}\text { Sesuai dengan sistem } \\
\text { berjalan selama proses } \\
\text { pengerjaan }\end{array}$ \\
\hline Programer & $\begin{array}{l}\text { 1. Membuat login pada Perubahan permintaan akibat eror } \\
\text { 2. Testing Sistem }\end{array}$ & $\begin{array}{l}\text { Sesuai dengan permintaan } \\
\text { dan keadaan saat proses } \\
\text { pengerjaan proyek }\end{array}$ \\
\hline ICT & $\begin{array}{l}\text { 1. Pertemuan dalam penentuan dan persetujuan anggota tim } \\
\text { pelaksana } \\
\text { 2. Penentuan desain sistem yang diimplementasikan } \\
\text { 3. Menghitung estimasi biaya perangkat }\end{array}$ & \\
\hline
\end{tabular}

\subsection{Realization}

Pada tahap ini dilakukan proses konfigurasi pada aplikasi SAP berdasarkan dokumen blueprint yang telah dibuat sebelumnya. Proses konfigurasi ini akan menghasilkan urutan proses konfigurasi dan data yang harus diinputkan kedalam aplikasi, sehingga aplikasi SAP-ERP dapat berjalan sesuai dengan kebutuhan perusahaan. Integration testing juga dilakukan pada tahap ini, tujuan dari pengujian ini yaitu untuk memastikan bahwa konfigurasi yang dilakukan telah berjalan sesuai dengan kebutuhan perusahaan, sehingga integrasi pada modul quality management dapat dilakukan[13].

\subsection{Final Preparation}

Pada tahap ini dilakukan proses percobaan pada proyek yang telah dikerjakan dan dilakukan perbaikan lagi jika ditemukan bagian yang kurang tepat. Selanjutnya melakukan perpindahan data yang ada dari sistem yang lama ke sistemyang baru. Setelah dilakukan hal tersebut, maka diberikan pelatihan bagi pengguna yang akan menggunakan sistem tersebut[14].

\subsection{Go Live And Support}

Pada tahap ini tidak dilaksanakan dalam penelitian. Di tahap ini telah dilakukan implementasi sistem. Pada saat implementasi harus disertai dengan monitoring dan maintenance sistem[15]. Dalam tahap go live and support adalah melakukan monitoring 


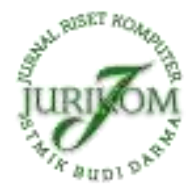

JURIKOM (Jurnal Riset Komputer), Vol. 7 No. 1, Februari 2020 e-ISSN 2715-7393 (Media Online), p-ISSN 2407-389X (Media Cetak)

dan pengawasan terhadap proyek implementasi system yang dilakukan, meskipun dalam hal ini proyek implementasi telah di implementasikan namun perlu di lakukan pengawasan yang berkelanjutan. Tujuan nya adalah mengurangi resiko resiko yang terjadi apabila dalam implementasi system terjadi gangguan yang tidak diinginkan. dalam tahap.

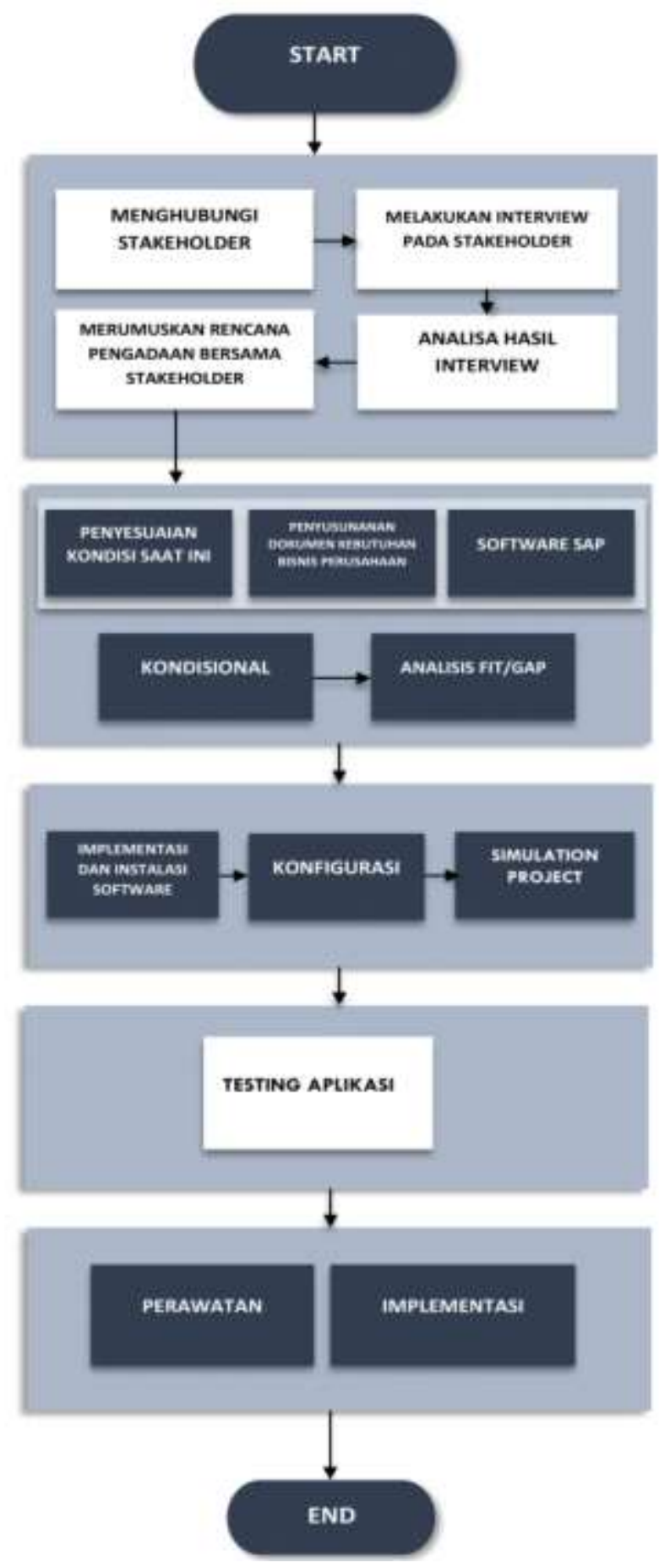

Gambar 3. Sistematika Pemecahan Masalah

\section{IMPLEMENTASI}

\subsection{Analisa Kondisi Saat Ini}

Berikut ini adalah analisis kondisi saat ini yang diperlukan perusahaan untuk mengukur rasio proses bisnis yang terjadi pada perusahaan dengan proses bisnis setelah adanya perencanaan implementasi SAP. Hasil dari analisis ini menjadi komponen utama dalam penyusunan proses bisnis usulan 


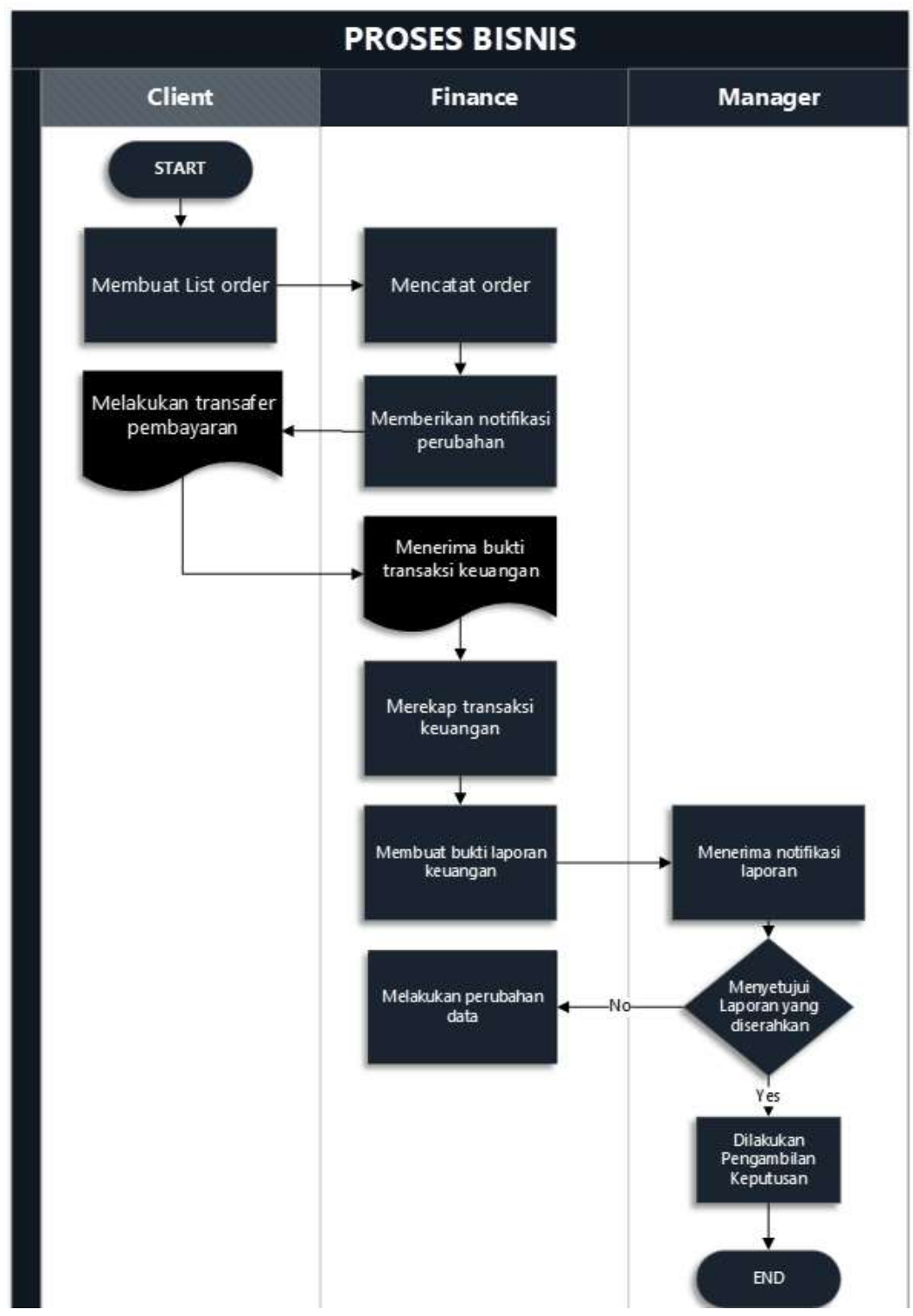

Gambar 4. Proses Bisnis Rancangan

\subsection{Identifikasi dan pengukuran data}

Kegiatan yang dilakukan dalam tahap ini Adalah mencatat setiap kejadian aktifitas transaksi yang terjadi dalam proses bisnis seperti pembelian, pembayaran, pemesanan. Data yang tercatat ini nantinya akan menjadi acuan sebagai alat ukur untuk melaksanakan tahap selanjutnya

\subsection{Pemrosesan dan pelaporan}

Tahap pemrosesan dan pelaporan dibagi menjadi dua yakni penggolongan. Dalam tahap penggolongan adalah mengklasifikasikan seluruh pencatatan transaksi yang telah dilakukan atau ringkasan detail keuangan baik pengeluaran yang terjadi pada saat ini, riwayat transaksi pada tahun sebelumnya maupun transaksi yang terjadi pada masa yang akan datang serta laba yang masuk maupun sebaliknya. hal ini sangat penting dilakukan selain memudahkan pencarian penggolongan ini memudahkan pihak keuangan dalam menghitung laba keseluruhan baik laba bersih maupun sebaliknya. Sedang ikhtisar adalah penyajian laporan akhir yang sudah klasifikasikan menjadi bentuk laporan yang biasanya dalam akuntansi dinamakan dengan neraca saldo atau jurnal akhir.

\subsection{Hasil Laporan}

Hasil dari seluruh kegiatan yang dilakukan, kemudian direkap dalam satu bukti laporan utama yakni financial statement atau laporan keuangan laporan keuangan ini berisi dari segi kegiatan transaksi yang terjadi baik dari biaya yang keluar . neraca 
saldo. Modal, riwayat labag rugi. Dan laporan ini nantinya diserahkan kepada pimpinan untuk menjadi sarana pengambilan keputusan

\subsection{Analisis dan Intersepsi}

Adalah aktifitas untuk menentukan dan memutuskan solusi yang tepat untuk setiap proses yang dilakukan. Dalam analisis dan interprestasi dilakukan penggabungan,pengukuran, dan pengambilan keputusan dari informasi yang telah dikumpulkan hal ini sangat penting untuk mengetahui forecast kemajuan perusahaan dimasa yang akan datang.

Tabel 4. Analisis Fit/Gap

\begin{tabular}{|c|c|c|c|c|c|c|}
\hline \multirow[b]{2}{*}{ No } & \multirow[b]{2}{*}{ Kebutuhan bisnis } & \multirow[b]{2}{*}{ Aktifitas } & \multicolumn{3}{|c|}{ Pemenuhan } & \multirow[b]{2}{*}{ Solusi } \\
\hline & & & $\mathrm{N}$ & $\mathrm{P}$ & $\mathrm{F}$ & \\
\hline 1 & $\begin{array}{lr}\text { Proses } & \text { kegiatan } \\
\text { transaksi mulai dari } \\
\text { pembayaran } & \text { yang } \\
\text { dilakukan } & \text { antara } \\
\text { client. } & \end{array}$ & $\begin{array}{l}\text { Adanya sistem yang dibutuhkan yang } \\
\text { berfungsi sebagai pencatat sehingga } \\
\text { kegiatan transaksi yang berhubungan } \\
\text { dengan pembayaran dapat terekap } \\
\text { dalam sistem secara otomatis. }\end{array}$ & $\sqrt{ }$ & & & $\begin{array}{l}\text { Pihak keuangan dapat mencatat } \\
\text { seluruh kegiatan transaksi dan } \\
\text { client dapat menerima notifikasi } \\
\text { pembayaran yang dilakukan. }\end{array}$ \\
\hline 2 & Pembuatan Laporan & $\begin{array}{l}\text { Terdapat fiitur yang dapat merekap } \\
\text { seluruh kegiatan transaksi keuangan } \\
\text { yang diinginkan menjadi satu bentuk } \\
\text { bukti transkrip. }\end{array}$ & & $\sqrt{ }$ & & Terdapat SAP Report \\
\hline 3 & Penggolongan Biaya & $\begin{array}{l}\text { Adanya sistem yang dapat } \\
\text { mengklasifikasikan biaya baik biaya } \\
\text { yang terjadi pada tahun ini maupun } \\
\text { tahun yang akan datang. }\end{array}$ & & & $\sqrt{ }$ & $\begin{array}{l}\text { Fitur yang dapat otomatis } \\
\text { menampilkan info biaya dari } \\
\text { tanggal transaksi yang } \\
\text { terjadidari tahun sekarang } \\
\text { maupun tahun yang akan datang }\end{array}$ \\
\hline 4 & $\begin{array}{lr}\text { Perhitungan jumlah } \\
\text { yang berhubungan } \\
\text { dengan } & \text { transaksi } \\
\text { keuangan } & \end{array}$ & $\begin{array}{l}\text { Adanya Sistem yang dapat menghitung } \\
\text { secara otomatis transaksi keuangan } \\
\text { yang terjadi }\end{array}$ & $\sqrt{ }$ & & & $\begin{array}{l}\text { Terdapat jumlah yang muncul } \\
\text { ketika }\end{array}$ \\
\hline 5 & $\begin{array}{l}\text { Terintergrasi dengan } \\
\text { sistem pimpinan }\end{array}$ & $\begin{array}{l}\text { Adanya sistem yang diperlukan yang } \\
\text { dapat otomatis terhubung dengan } \\
\text { sistem pimpinan sehingga } \\
\text { memudahkan pimpinan mengetahui } \\
\text { laporan keuangan tanpa melihat sistem } \\
\text { yang dipegang oleh staff. }\end{array}$ & & $\sqrt{ }$ & & $\begin{array}{l}\text { Terintegrasi dengan sistem } \\
\text { pihak manager sehingga seluruh } \\
\text { aktifitas transaksi keuangan } \\
\text { secara otomatis dapat dilihat dan } \\
\text { dipantau melalui sistem pihak } \\
\text { manager. }\end{array}$ \\
\hline
\end{tabular}

\section{KESIMPULAN}

Dari perencanaan implementasi SAP yang dilakukanpada PT XYZ. mulai dari Project Preparation, maka dapat diambil suatu pengambilan keputusan bahwa, dalam PT XYZ guna menunjang proses bisnis perusahaan yang ada , maka dibutuhkan tahap tahap yang dipakai yakni Project Preparation, Blue Print, Realization, Final Preparation dan Go Live and Support. Dimana telah disampaiakan dalam penelitian, proyek perencanaan implementasi yang rencanakan ini diambil sepenuhnya satu departemen finance dalam satu instansi berbasis produksi. Maka penulis sepenuhnya berkejasama dengan stakeholder dalam merencanakan implementasi terhadap sistem, baik dari segi aktifitas,waktu,biaya dan sumber daya infrastruktur. Sehingga didapatkan hasil perencanaan yang akurat. Dalam perencanaan implementasi ini diambil melalui metode wawancara bersama dengan stakeholder PT XYZ dalam perkiraan perencanaan kebutuhan per kegiatanya penulis menggunakan software yakni berbasis erp SAP (System Application and Product) adalah suatu software yang dikembangkan untuk mendukung suatu organisasi dalam menjalankan kegiatan operasionalnya secara lebih efisien dan efektif. SAP . sebelum melaksanakan perencanaan implementasi hal yang perlu dilakukan adalah mengetahui analisis kondisi saat ini yang diperlukan perusahaan untuk mengukur rasio proses bisnis yang terjadi pada perusahaan .

\section{REFERENCES}

[1] M. S. Kusnendi, "Konsep Dasar Sistem Informasi,” Konsep Dasar Sist. Inf., 2014

[2] S. Meza, "Jurnal Teknologi dan Sistem Informasi (TEKNOSI)," Pembang. Sist. Inf. Rawat Jalan Berbas. WEB Dengan Fitur Mob. Pada Puskesmas Tarok Kota Payakumbuh, 2017.

[3] P. Widyaningsih, M. Mustafid, and A. F. Rochim, "Perencanaan Strategis Sistem Informasi Pada Institusi Pendidikan Tinggi Menggunakan Analisis 
JURIKOM (Jurnal Riset Komputer), Vol. 7 No. 1, Februari 2020 e-ISSN 2715-7393 (Media Online), p-ISSN 2407-389X (Media Cetak)

Critical Success Factors," J. Sist. Inf. BISNIS, 2014.

[4] N. B. F, Rispianda, and G. L Permata, "Rancangan Implementasi Enterprise Resource Planning Berbasis Open Source Menggunakan Software Odoo Pada Lini Bisnis Modul Surya Di Perusahaan Elektronika," Reka Integr., 2016.

[5] Y. Putri, A. Y. Ridwan, and R. W. Witjaksono, "Pengembangan Sistem Informasi Berbasis Enterprise Resource Planning Modul Purchasing (MMPUR) pada SAP dengan Metode ASAP di PT. Unggul Jaya Sejahtera," J. Rekayasa Sist. Ind., 2017.

[6] A. Susanto, "Implementasi Sistem Erp (Enterprise Resources Planning) Pt Pos Indonesia : Sebuah Inisiasi Dan Strategi," J. PPI Kominfo, 2013.

[7] C. A. Lestari, "Implementasi Odoo Dengan Modul Accounting and Finance Di SD Islam Tunas Mandiri," J. Inform. Terpadu, vol. 3 No.1, pp. 1-6, 2017.

[8] Ayu Laely Qomariah, "Penerapan System Application And Product (SAP) Pada Administrasi Kepegawaian Di PT KAI (Persero) DAOP 8 Surabaya," J. Penerapan Syst. Appl. Prod., 2015.

[9] E. W. T. Darmaningrat, H. M. Astuti, and A. I. Rizqy, "Analisis Kesenjangan dan Pemodelan Proses Bisnis Human Capital Management pada PTPN XI berdasarkan Best Practice SAP,” J. Teknol. Inf. dan Ilmu Komput., 2019.

[10] M. H. Kurniawan, R. R. Saedudin, R. W. Witjaksono, F. R. Industri, U. Telkom, and K. Kunci, "Pengembangan Sistem Erp Warehouse Management Menggunakan Odoo Pada Pt. Putri Daya Usahatama Dengan Metode Asap,” eProceedings Eng., 2016.

[11] W. Witjaksono et al., "Pengembangan Sistem Informasi Berbasis Enterprise Resource Planning Modul Quality Management Menggunakan Sap Dengan Metode Asap Pada Bagian Produksi Pt. Len Industri," eProceedings Eng., 2016.

[12] Y. Indanea, R. R. Saedudin, and R. W. Witjaksono, "Implementasi Sistem Produksi Berbasis Odoo Pada PT. Primarindo Asia Infrastructure Tbk Dengan Metodologi ASAP," eProceedings Eng., 2016. 